\title{
LOCATION OF SPEED CONTROL CAMERAS ON HIGHWAYS: A GEOSPATIAL ANALYSIS
}

\author{
Garis CORONELL, Julián ARELLANA, Víctor CANTILLO \\ Dept of Civil and Environmental Engineering, University of the North, Barranquilla, Colombia
}

Submitted 27 May 2019; accepted 9 January 2020

\begin{abstract}
This research proposes a methodology to identify critical sections of highways where the location of speeding control may be beneficial. The method relies on a spatial and statistical analysis of infrastructure risks, along with traffic accident frequency and severity. A relevant feature of this methodology is related to its potential to be used in areas where there are no detailed historical records about traffic crashes, which is common in Global South countries. We applied the methodology to a rural road network in Colombia, where a recent law established that technical criteria should support the location of speed cameras. The case study uses accident information from six years, and risk data from a road safety audit carried out in the area under study. Even though historical records of accidents in the area were not fully available, the methodology allowed prioritising speed camera installations in the zone and identifying the relevant variables to define camera location. The relevant variables were the geometric characteristics of the road, traffic flows, risk factors, and proximity to populated centres. The use of speed controls should be part of a road safety management system, which allows defining camera location according to robust technical criteria.
\end{abstract}

Keywords: speeding control cameras, traffic crashes, statistical analysis, kernel density, highway safety, road safety.

\section{Notations}

ADT - average daily traffic;

FWI - fatalities and weighted injuries;

GDP - gross domestic product;

GIS - geographic information system;

ZIP - zero-inflated with Poisson.

\section{Introduction}

The consequences of traffic accidents are a public health concern that requires investments and strategies for improving road safety. The World Health Organization reports that nearly 1.3 million people die every year while 20 to 50 million people suffer non-fatal injuries as a result of traffic crashes (WHO 2015). Within the social costs of accidents, the most important are economic losses to victims, relatives, and community in general for medical treatment and productivity reduction. Such costs are around 1 to $3 \%$ of the GDP of the countries. According to the Global Status Report on Road Safety: Time for Action (WHO 2009), about $90 \%$ of the deaths caused by traffic crashes occur in low- and middle-income countries besides having only $48 \%$ of the vehicles registered in the world.
The frequency and severity of traffic crashes increase depending on elements such as the number and type of intersections, vehicular flow, the presence of pedestrians (Tulu et al. 2015), motorcycle and cyclist flows, land use, type of road, and speed (Chen et al. 2016). Among these factors, speeding is a crucial determinant of road safety (Aarts, Van Schagen 2006; OECD 2006). Excessive and inadequate speed is a critical problem in many countries, often contributing to one-third of fatal accidents and an aggravating factor in most of them.

Speeding increases the severity and the probability of occurrence of accidents (GRSP 2008; Elvik 2009). According to Pikūnas et al. (2004), decreasing speed by $10 \mathrm{~km} / \mathrm{h}$, the number of accidents decreases by $20 \%$, number of killed - by $30 \%$ and the number of injured - by $40 \%$. Moreover, a study in Chile, CoNaSeT (2002) concludes that an increase of $1 \mathrm{~km} / \mathrm{h}$ of speed on the road increases injuries by $5 \%$ and fatalities by $7 \%$. On the other hand, ETSC (1995) argues that each reduction of $1 \mathrm{~km} / \mathrm{h}$ in the average speed implies a decrease of $3 \%$ in the number of accidents with injuries.

*Corresponding author. E-mail: gcoronell@uninorte.edu.co 
The influence of speed on the frequency and severity of crashes has justified the implementation of technological tools for controlling speed limits such as fixed and mobile speed cameras. These should be located in areas of high accident frequency and potential risk of occurrence. Therefore, a relevant aspect of these programs is to make an adequate identification of these sites to optimise resources and achieve greater effectiveness.

In most cases, traffic authorities justify the location of speed cameras by the frequent occurrence of high impact crashes or by requests from the community. That is, they do not follow a systematic methodology based on the historical frequency and severity of crashes and the road and traffic characteristic to define their location. As a consequence, in many cases, the use of speed cameras is controversial and perceived as arbitrary (Delaney et al. 2005). The most frequent controversy is about the revenue from fines because opponents claim that cameras aim to raise revenue rather than to increase safety.

This paper proposes a methodology to identify critical road sectors where speeding controls through photo-radar cameras would be beneficial. The method allows identifying high-risk areas by considering information on deaths, injuries, characteristics of the roads, the presence of urbanised areas, and existing risks. The analysis focuses on rural roads and allows developing plans for speed management and accident control. The methodology is applied to the road network of the Atlantic Department of Colombia, located in northern Colombia with the Caribbean Sea to its north.

\section{Literature review}

Appropriate policies and tools are required for speed limit enforcement considering the influence of speed on the frequency and severity of traffic crashes. According to Povey et al. (2003), increasing the level of control, legal requirements and the perception of risk influence the behaviour of the driver, encouraging them to stay within the imposed speed limits and, thus, decrease the occurrence and severity of crashes. Nowadays, among the most used controls are manual inspections with police regulator stations and equipment for speed measurement, automatic controls with the use of cameras, technologies in vehicles for speed control based on regulations, and the imposition of speed limits, penalties, and education programs. From the above-mentioned controls, the automatic control is a strategy that has a significant impact on both users and control entities since it presents advantages such as the highest probability of detection of violators and penalties, despite the higher initial investment over that of manual controls (GRSP 2008). Also, users perceive automatic control as more objective control (Mäkinen et al. 2003). Table 1 presents some case references in which the accident rates were reduced by using cameras for speed control.

Despite the already proven benefits in reducing accidents, these measures generate controversy in the community and some socioeconomic sectors, which consider them as a mechanism whose primary objective is to raise revenue rather than increase safety. In Chile, after the implementation of photo-radars in the mid-1990s, they were

Table 1. Cases of accident rates reduction with the use of cameras for speed control

\begin{tabular}{|l|c|l|}
\hline \multicolumn{1}{|c|}{ City/region/ country } & Reduction in crashes rates [\%] & \multicolumn{1}{c|}{ Source } \\
\hline Kuwait & 15 & Aljassar et al. (2004) \\
\hline Germany & 51 & Weber, Jahrig (2010) \\
\hline Guangdong, China & 32.5 & He et al. (2013) \\
\hline Flanders & 8 & \multirow{2}{*}{ De Pauw et al. (2014a, 2014b) } \\
\hline Belgium & 29 (severity) & Carnis (2008) \\
\hline \multirow{2}{*}{ France } & 23 & Blais, Carnis (2015) \\
\cline { 2 - 3 } & 19.7 & Novoa et al. (2010) \\
\hline Spain & 30 & DDOT (2013) \\
\hline Washington, DC, US & 17 & Turner, Polk (1998) \\
\hline Paradise Valley, AZ, US & 40 & Berkuti, Osburn (1998) \\
\hline National City, CA, US & 51 & DNIT (2012) \\
\hline Goiás, Brazil & 11.6 & Cameron et al. (2003) \\
\hline Minas Gerais, Brazil & 7 & Christie et al. (2003) \\
\hline Victoria, Australia & 41 & Hess, Polak (2003) \\
\hline South Wales, UK & 51 & Oei (1996) \\
\hline Cambridgeshire, UK & 32 & Goldenbeld, Van Schagen (2005) \\
\hline \multirow{2}{*}{ Netherlands } & 35 & Høye (2015) \\
\hline Norway & 21 &
\end{tabular}


subsequently banned as they were used to increase private and municipal income rather than to improve road safety. Paredes et al. (2006) concluded that the non-use of this technology had increased human losses associated with crashes. For the sample analysed, net costs are in the range between 83 and 600 million dollars in present value of the year of study.

In Colombia, the use of speed cameras dates from the mid-2000s. In most cases, they were installed by private companies at the discretion of local authorities, without an objective criterion to define their location. The fact that the private companies obtained a profit proportional to the imposed fines caused people to distrust the system since the cameras were perceived as a mechanism of corruption, not for safety. In response to the complaints, in 2017, a law was issued in which the Ministry of Transport of Colombia is commissioned to regulate the location of speed cameras.

Another controversy around speed cameras is about their effectiveness of changing driver behaviour. For instance, De Pauw et al. (2014a, 2014b) and Shim et al. (2015) indicate that drivers abruptly slow down as they approach the camera and increase speed after passing it to resume their initial speed. This may increase the risk of accidents and move the problem to another place. Therefore, it is imperative to define the installation of this tool from objective analyses to ensure that they fulfil their mission of reducing social losses due to traffic crashes. Speed cameras should not be taken as an isolated solution, but as a policy integrated within a complete traffic management system.

Parallel to the identification of the need to implement speed controls, the question arises as to where to locate them. It is essential to have speed reductions in strategic sites to adequately evidence the decrease in accident rates guaranteeing the success of these programs, justifying the investment, and avoiding negative perceptions in public opinion. In general, the methodologies reviewed gave recommendations and considered criteria such as the identification of areas characterised by historically high accident crash rates, greater severity and a higher level of risk identified by users or authorities. Other variables such as the type of road and the environment, including the surrounding land use, are also relevant.

The DfT (2007) through its programs for safer routes has defined a methodology for the implementation and use of cameras for speed control. The method defines categories of zones that allow for the establishment of priorities and types of solutions (fixed, mobile, among others). For selecting the potential locations of the cameras the following need to be considered: an analysis of accident data (recommended for a minimum period $3 . . .5$ years); analysis of causes of collisions; review of signalling status; existing infrastructure, and revision of the speed limits set and speed 85 percentile data. The approach permits analysing the degree of compliance within limits established in the study area; analysing the level of collisions by numerical scales, and whether it is convenient to establish this solution or if another alternative is more cost-effective from an engineering point of view. Li and Graham (2016) analysed the effect of the reduction of accidents in the sites where cameras were installed according to the criteria defined above. Results show that injuries decreased, particularly when compared with other locations without a specific methodology.

In Chile, the method of the Ministry of Transport and Telecommunications of Chile (ARISTO Consultores Ltda 2011) raises a simplistic analysis that later complements with ex-post evaluations. This analysis considers infractions and databases of accidents with injuries and deaths (3...5 years). Information is spatially located and aggregated according to social costs associated with the consequences of the crashes on people. This spatial analysis allows for the identification of zones of higher concentration (severity and frequency) that are prioritised according to the defined costs. From the prioritisation and establishing of relationships between accidents and infractions, different options for physical improvement (changes in infrastructure or geometry), operational (speed limits revision) or safety (low-cost countermeasures) are analysed. Physical improvement on some selected locations are executed, followed by an evaluation period of one year. The remaining locations are included in the speed control program with the use of cameras, followed by evaluations to monitor the efficiency of the measures.

For identifying crash hot-spots, researchers have used a wide range of statistical tools such as Poisson, Gamma, binomial negative, ZIP and Bayesian models. Most studies focused on determining variables that determine the frequency and severty of traffic crashes. Table 2 presents some of the related studies.

This paper proposes a methodology that allows the identification of zones with high accident rates where the installation of cameras for speed control to reduce crashes rates would be beneficial. The method is based on statistical analysis and kernel type spatial concentration with information on injuries, fatalities, and potential risks on the roads of the studied area.

The proposed approach is particularly useful in areas where there is not complete nor very detailed historic crash information. This is a determining limitation to give adequate support to policies and is a prevalent situation in developing countries, where the quality of information uses to be low due to lack of resources or technology, and poor planning culture. The methodology is supported by GIS tools and involves spatial statistical analysis for the planning of a crash management system, providing adequate technical assistance to define the location of controls through mobile and fixed cameras.

\section{Methodology}

The method identifies critical areas with high crash rates in which the location of cameras for speed control is recommended. The process is summarized in the six steps detailed below. 
Table 2. Background of methodologies used for road accident analysis

\begin{tabular}{|c|c|c|}
\hline Objective & Methodology & Source \\
\hline $\begin{array}{l}\text { Apply spatiotemporal clustering technique to identify clusters of } \\
\text { injured pedestrians and investigate the influence of personal and } \\
\text { environmental factors on pedestrian injuries }\end{array}$ & $\begin{array}{l}\text { Spatiotemporal clustering technique } \\
\text { and logistic regression model }\end{array}$ & Dai (2012) \\
\hline $\begin{array}{l}\text { Investigate spatial techniques for quantifying road accident hot- } \\
\text { spots }\end{array}$ & $\begin{array}{l}\text { Hot-spots, kernel, network analysis and } \\
\text { census output area estimation }\end{array}$ & Anderson (2007) \\
\hline $\begin{array}{l}\text { Develop a methodology to identify and prioritise high-risk areas } \\
\text { of deaths and injuries due to traffic accidents in urban areas }\end{array}$ & $\begin{array}{l}\text { Moran index, kernel and hot-spots } \\
\text { (urban areas - Colombia) }\end{array}$ & $\begin{array}{l}\text { Martínez et al. } \\
(2014)\end{array}$ \\
\hline $\begin{array}{l}\text { Estimate the areas with the highest density of road traffic } \\
\text { accidents with fatalities in peninsular Spain, in the period from } \\
2008 \text { to } 2011 \text {, using GIS }\end{array}$ & $\begin{array}{l}\text { Kernel density and nearest neighbour } \\
\text { (Spain) }\end{array}$ & $\begin{array}{l}\text { Gómez-Barroso } \\
\text { et al. }(2015)\end{array}$ \\
\hline $\begin{array}{l}\text { Use GIS as a management system for accident analysis and } \\
\text { determination of hot-spots in Turkey with statistical analysis } \\
\text { methods }\end{array}$ & $\begin{array}{l}\text { Kernel density and Poisson distribution } \\
\text { (vehicular accidents - Turkey) }\end{array}$ & $\begin{array}{l}\text { Erdogan et al. } \\
(2008)\end{array}$ \\
\hline $\begin{array}{l}\text { Evaluate and delineate road accident hot-spot in a zone where the } \\
\text { inadequate development of land transport network often leads to } \\
\text { traffic congestion and accidents }\end{array}$ & $\begin{array}{l}\text { Kernel density, Getis-Ord Gi } \\
\text { and Moran's I method of spatial } \\
\text { autocorrelation (accidents - India) }\end{array}$ & $\begin{array}{l}\text { Prasannakumar } \\
\text { et al. }(2011)\end{array}$ \\
\hline Model to estimate the number of accidents, fatalities and injuries & $\begin{array}{l}\text { Artificial neural network and a genetic } \\
\text { algorithm (Ankara, Turkey) }\end{array}$ & $\begin{array}{l}\text { Akgüngör, Doğan } \\
(2009)\end{array}$ \\
\hline Develop a method for identifying collision hot zones & $\begin{array}{l}\text { Kernel density (critical zones in } \\
\text { Regina - Canada) }\end{array}$ & Young, Park (2014) \\
\hline $\begin{array}{l}\text { Show the usefulness of GIS and point pattern techniques for } \\
\text { defining road-accident black zones within urban agglomeration }\end{array}$ & $\begin{array}{l}\text { Cluster techniques (grouping } \\
\text { tendencies - Belgium) }\end{array}$ & $\begin{array}{l}\text { Steenberghen et al. } \\
(2004)\end{array}$ \\
\hline $\begin{array}{l}\text { Analyse the distribution of accidents on roads, identifying the } \\
\text { main sections where they occur, as a first step to develop a } \\
\text { monitoring system }\end{array}$ & $\begin{array}{l}\text { Dynamic segmentation (grouping } \\
\text { tendencies - Mexico) }\end{array}$ & $\begin{array}{l}\text { Luna González, } \\
\text { Chias Becerril } \\
(1999)\end{array}$ \\
\hline $\begin{array}{l}\text { Examine the relationship between actual traffic accident location } \\
\text { and people's perception of hazardous location using geographic } \\
\text { information system }\end{array}$ & $\begin{array}{l}\text { Nearest neighbour index (distance } \\
\text { between accidents) }\end{array}$ & Koike et al. (2000) \\
\hline Explore factors associated with accident likelihood and severity & Bayesian logistic regression & Theofilatos (2017) \\
\hline $\begin{array}{l}\text { Establish the empirical relationship between traffic accidents } \\
\text { and highway geometric variables, traffic characteristics, and } \\
\text { environmental factor }\end{array}$ & $\begin{array}{l}\text { Classification and regression tree and } \\
\text { negative binomial regression model }\end{array}$ & $\begin{array}{l}\text { Chang, Chen } \\
(2005)\end{array}$ \\
\hline $\begin{array}{l}\text { Explore the relationship based on crash data collected on rural } \\
\text { two-lane highways in China }\end{array}$ & Partial proportional odds model & Ma et al. (2015) \\
\hline $\begin{array}{l}\text { Investigate the spatial variations in the relationship between the } \\
\text { number of zonal collisions and potential transportation planning } \\
\text { predictors }\end{array}$ & $\begin{array}{l}\text { Geographically weighted Poisson } \\
\text { regression models to that of generalized } \\
\text { linear models }\end{array}$ & $\begin{array}{l}\text { Hadayeghi et al. } \\
(2010)\end{array}$ \\
\hline $\begin{array}{l}\text { Compute spatial concentrations of point-based events on a } \\
\text { network to detect dangerous locations on the road of the city of } \\
\text { Brussels in Belgium }\end{array}$ & Monte Carlo simulation & $\begin{array}{l}\text { Steenberghen et al. } \\
\text { (2010) }\end{array}$ \\
\hline $\begin{array}{l}\text { Scrutinize the role of each group of vehicles in the likelihood of } \\
\text { accidents }\end{array}$ & $\begin{array}{l}\text { Poisson and negative binomial } \\
\text { regression models }\end{array}$ & $\begin{array}{l}\text { Ayati, Abbasi } \\
(2011)\end{array}$ \\
\hline
\end{tabular}

Step 1. Information gathering. The method relies on spatial analyst and spatial statistics extensions commonly available in any GIS platform. The required input information includes geographical layers, in vector format or raster files in a grid format, describing the population in the zone, road characteristics, accident records, and potential risks on the highways.

Step 2. Severity factor for deaths and injuries. From the georeferenced information of fatalities and injuries in accidents, a severity factor should be applied for each event to determine the equivalence between deaths and injuries.
The product of this step is a new geographical layer containing the spatial location of FWI. FWI represents the sum of injuries and fatalities multiplied by an equivalency factor. In practice, FWI represents an indicator of equivalent injury events considering both, injuries and deaths. FWI is a relevant variable for the spatial analysis that will be implemented next.

Step 3. Kernel analysis. This step comprises an analysis of accident and potential accident risk concentration using the method of kernel density (Rosenblatt 1956), the FWI layer, and the potential accident risk layer. The kernel estimator is a non-parametric interpolation method 
where each pixel has a specific density value (Buzai, Baxendale 2015). It consists of the calculation of a probability density function, which generates a weighted sum of the distribution of the variable to be analysed, capturing the contribution or influence of the data. In the case of analysis, it allows for obtaining global trends of the spatial distribution of incidents generating a raster layer from the accident and the potential risk information. The following expression calculates the value of each pixel in the raster:

$$
f(x)=\frac{1}{n \cdot h} \cdot \sum_{i=1}^{n} K\left(\frac{x-x_{i}}{h}\right),
$$

where: $x$ is the pixel in which the density is estimated (it is a random variable with a continuous probability distribution which has a random sample of $n$ independent observations $x_{1}, x_{2}, x_{3}, \ldots, x_{n}$ (Rodríguez Ojeda 2014)); $f(x)$ is the probability density function; $n$ is the number of observation; $h$ is the bandwidth or radius of search, it should tend to 0 to ensure that $f(x)$ tends to the true density at the analyzed point; $K$ is the weight function called kernel that can correspond to a function of uniform type, triangular or Gaussian, among others (in this paper, the kernel function is based on the quartic kernel function (Silverman 1998)).

This procedure allows the representation of the variations in the geographical distribution of the parameters under study (accident data and potential risk information) defining areas of concentration and dispersion. Those areas allow for identifying patterns of spatial behaviour. In this way, the value assigned to a pixel corresponds to the calculation made on the number of entities found around it according to a defined search radius. Therefore, the points farthest from the analysed pixel will have less weight and less density (Cardozo et al. 2010).

The products of this step are two raster maps. The first raster layer contains a grid in which each cell corresponds to the number of incidents per square kilometre. The second raster layer contains a grid in which each cell contains the number of risks per square kilometre.

Step 4. Standardization of critical areas. The kernel density analyses, performed in the previous step, provide an approximation of the areas where increased controls are required to decrease the probability of accidents. However, it is necessary to prioritise the places in which to intervene by identifying the highest risk areas. For this, the two raster layers are normalised using equation:

$$
Z_{\text {pixel }}=\frac{X_{\text {pixel }}-\underline{X}}{\sigma},
$$

where: $Z_{\text {pixel }}$ is the normalized pixel value; $X_{\text {pixel }}$ is the initial value in the pixel result of the kernel analysis for each type of data; $\underline{X}$ is the arithmetic mean of the initial pixel values (kernel raster); $\sigma$ is the standard deviation of the initial pixel values (kernel raster).

This step is done to compare and combine information from the two data sources. This operation generates two new raster layers, one standardised FWI and another one of standardised risks. Those pixels with values greater than or equal to $1.96(Z \geq 1.96)$, considering a $5 \%$ significance level of $5 \%$, correspond to the most critical points in the map, assuming a normal distribution of the pixel values.

Step 5. Selection of critical zones. A combined analysis of the information related to FWI and risks, previously normalised, is performed in this step to allow prioritising the critical areas. A new raster is created by intersecting the two standardised layers generated in the previous step. The outcome of this step is a new raster layer containing the areas with statistical significance for FWI and risks.

Step 6. Identification of the location of the cameras. It is proposed to locate the cameras in the zones identified in the raster generated in Step 5, where there is statistical significance due to the presence of risks and accidents. Those areas where cameras are already installed will be excluded.

In case the required investment is very high and exceeds the allocated budget, a suggestion is to prioritise near urban areas and in the sectors where the measured velocity is above that allowed regularly. Alternatively, a stepwise installation can be made by the investment plans of the entity.

\section{Case study}

The methodology was applied to the rural roads network of the Atlantic Department of Colombia. The Atlantic Department has an area of $3386 \mathrm{~km}^{2}$ and a population of around 2.5 million inhabitants (DANE 2006). According to the INMLCF (2015), Atlantic is among the ten departments with the highest number of traffic accidents in the country with 229 deaths and 1928 injuries reported during 2016. Similar to the tendency around the country, about $41 \%$ of fatalities occur in the context of rural roads.

ArcGIS $^{\circledR}$ (https://www.arcgis.com) was used to perform all the spatial analysis in this paper, but other similar GIS tools may also be appropriated. The necessary information of the study area is detailed below.

Municipal limits and road network. These geographic files contain the political division and the rural highways of the area, respectively. The road network layer (IGAC 2011) included information about length, the category of the roads, and ADT. The municipal limits layer contains polygons describing urban zones and populated centres within the area of interest (CorMagdalena 2003). The highway network of the Atlantic Department is comprised of two categories according to the National Roads Institute (INVÍAS 2015). The first category corresponds to the principal arterial system: Route 25, Route 90 and Route $90 \mathrm{~A}$. The second is the collector road system. Figures 1 and 2 show the road network of the Atlantic Department and their corresponding ADT (INVÍAS 2015).

Traffic speed on the road network. A spot speed study using a radar gun in the stations presented in Figure 3 (UniNorte 2013) was conducted to obtain speeds on the road network. For the allocation of the speed of the roads (Figure 4), the value corresponding to the operating speed (85th percentile) was assigned to the arterial roads from the field measurements. 


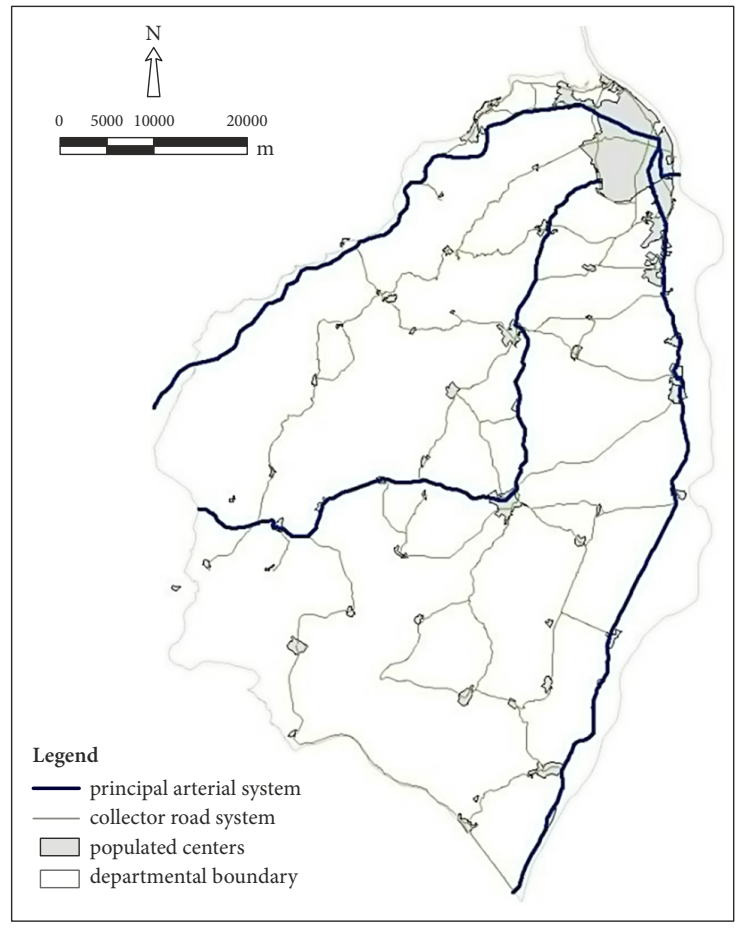

Figure 1. Road network of the Atlantic Department (INVÍAS 2015)

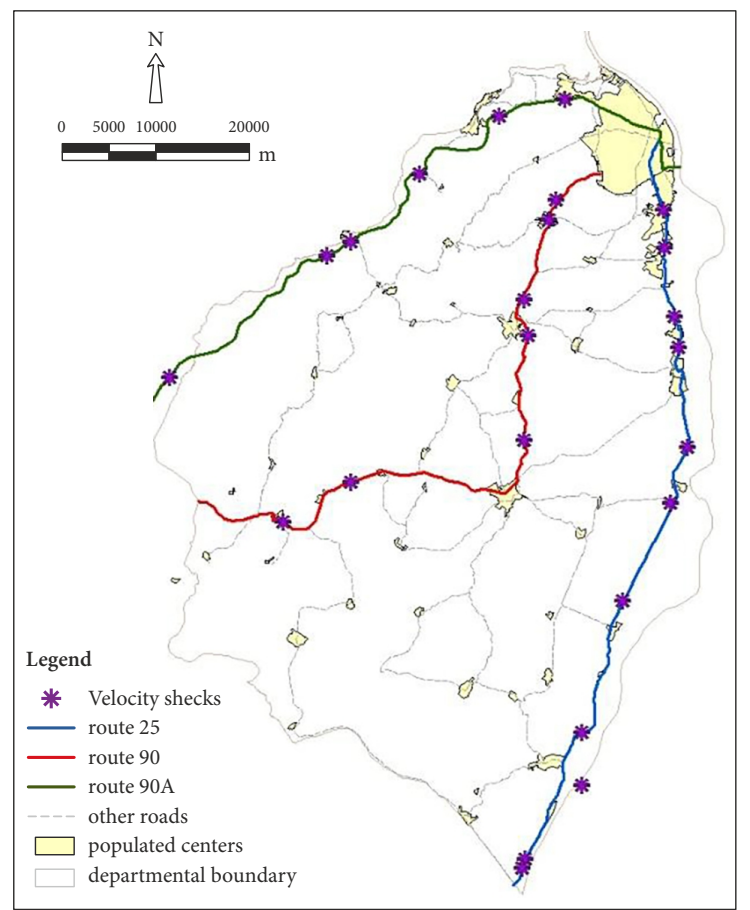

Figure 3. Speed checks on the highways of the Atlantic Department

Dead and injured in road accidents. This layer contains the georeferenced information of fatalities and injuries in road crashes. Such information should be gathered for at least three years to apply the methodology correctly. The data of the case study involves information on injury crashes (dead and injured) from 2007 to 2012, which was georeferenced and is shown in Figure 5. The database

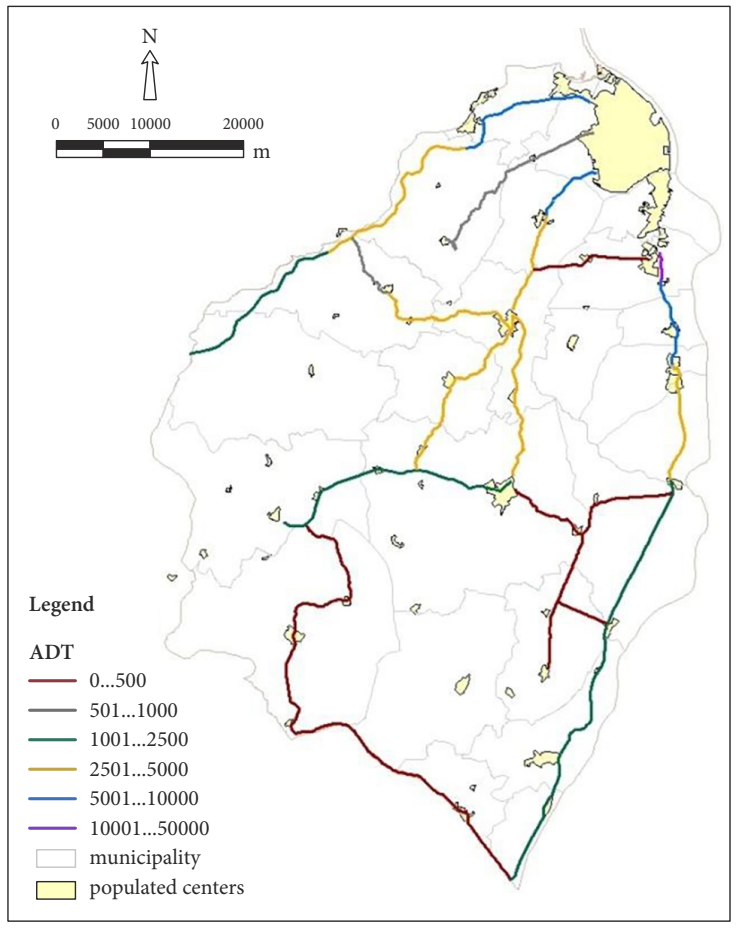

Figure 2. ADT in the road network of the Atlantic Department (INVÍAS 2015)

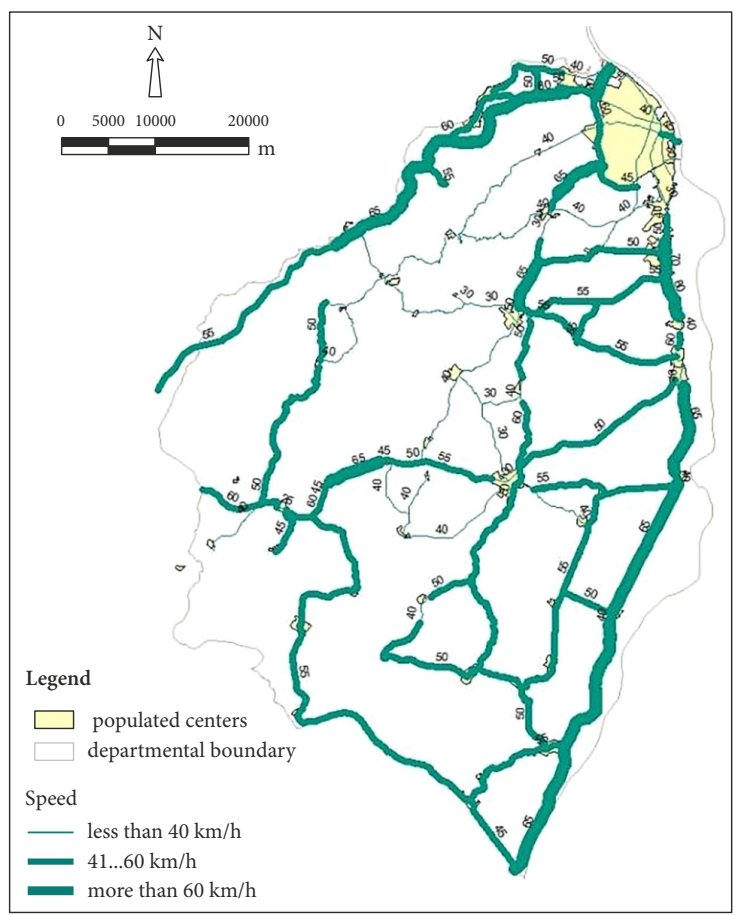

Figure 4. Speed limits on roads

also contains information about the injured people (i.e., age, sex, marital status), characteristics of the vehicles involved in the crash and conditions of the event (i.e., location, time, type of crash and weather). It is important to note that this layer contemplates accident data only on the arterial routes. Local authorities do not have historical accident records in the collector road system. 
Potential hazards on the road. Unsafe or dangerous elements must be georeferenced. These include the location of curves, access-point density, road obstructions, poor lighting, design inconsistencies, intersections with risks, inexistent or poor signalling, visibility problems, pavement in bad condition, and overturning hazards, among others. The potential hazards on the whole road network for the case study came from an inventory of risks on the roads carried out as a part of a road safety audit (Uni-

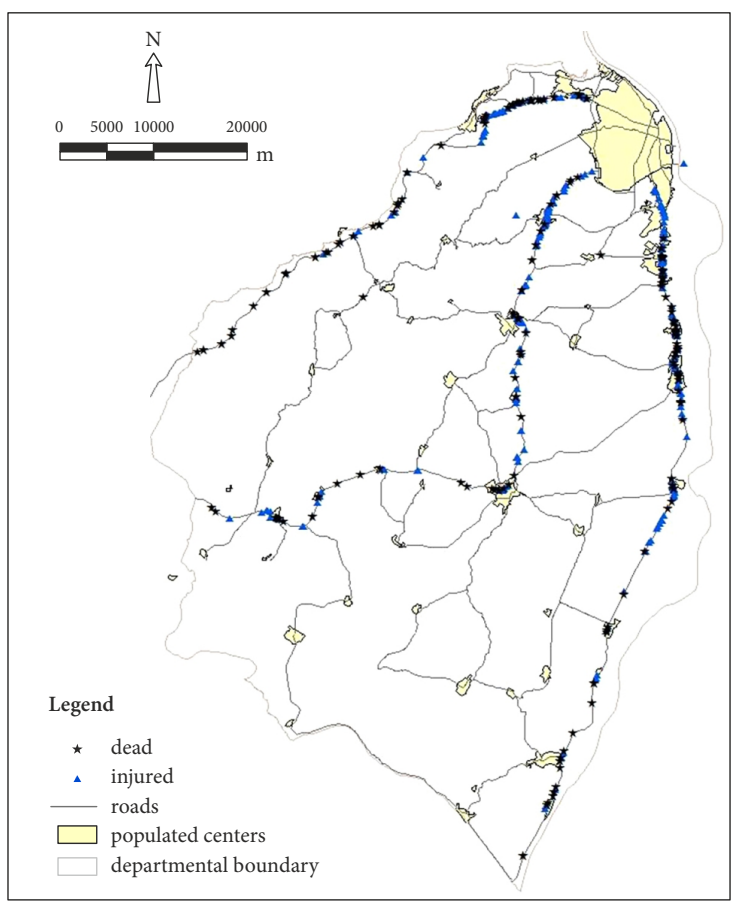

Figure 5. Deaths and injuries from 2007 to 2012

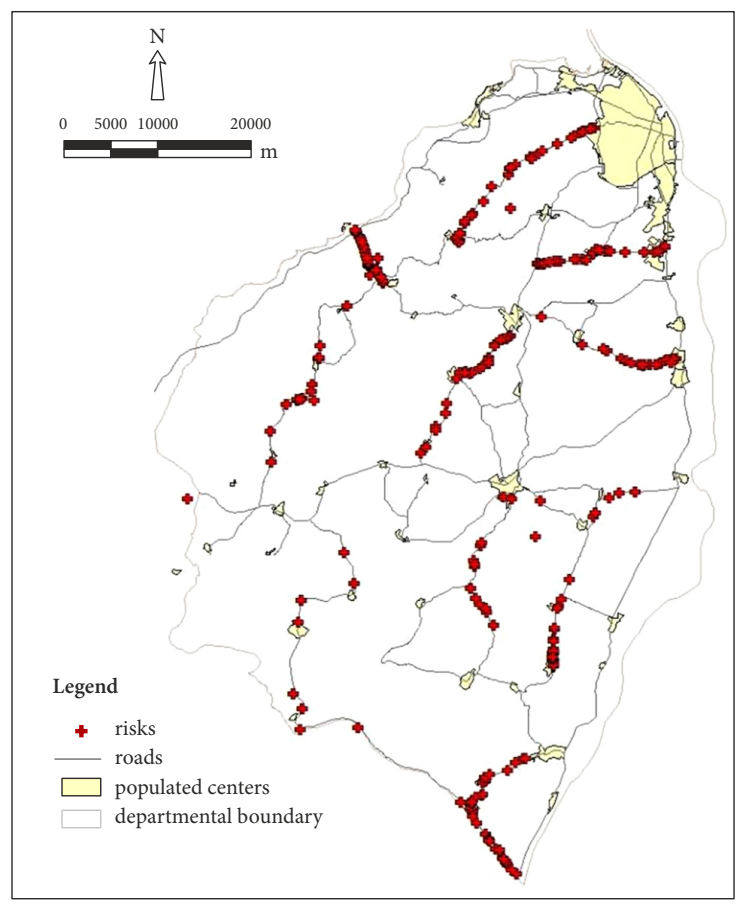

Figure 6. Location of risks
Norte 2013). The road safety audit was performed following criteria defined by the iRAP Road Star Rating Index (Harwood et al. 2010). The analysis makes it possible to identify the risks encountered and proposing a subsequent treatment. The information regarding the location of risks is presented in Figure 6.

Location of existing cameras. This geographical layer contains the current location of existing cameras. Concerning the existing cameras in the study area, 15 are currently in operation, of which 4 are located on Route 90A, 3 are - on Route 90, 7 are - on Route 25, and only 1 is located on a collector road. Figure 7 presents the location of the cameras currently in operation.

The equivalence factor was taken from the study performed by the CFPV (2013) where a fatal crash is equivalent to 4 injury crashes. This relation was taken according to the equivalence for the Colombian case but may be different in other contexts. The International Road Assessment Program (iRAP) establishes a model based on the visual inspection with a video recording of the road infrastructure and takes encoded information of the characteristics that determine the level of safety for the users (Vecino-Ortiz, Hyder 2014). These variables determine a road safety rating. For the current analysis, only accidents with consequences (fatalities and injuries) were considered. However, if there is reliable crash information including no-injury, it could be incorporated into the analysis.

\section{Results and discussion}

The kernel analysis was performed in $\operatorname{ArcGIS}^{\circledR}$ using a search radius of $564 \mathrm{~m}$. According to the work scale and amount of data the size of the pixel used was $200 \mathrm{~m}$.

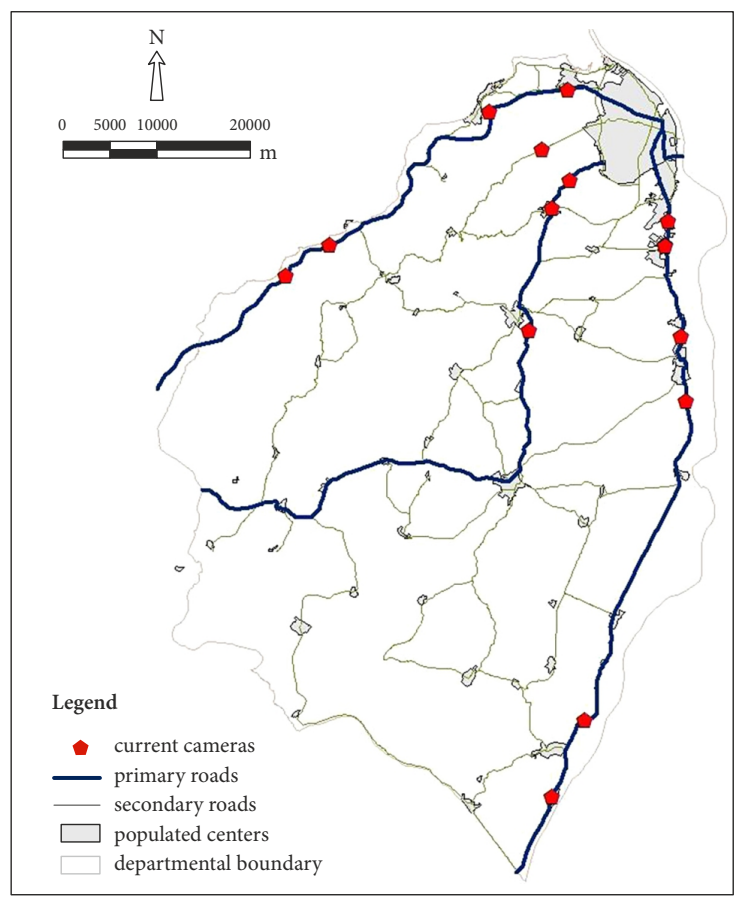

Figure 7. Current location of cameras 
Figure 8 presents the kernel density analysis of FWI. There is a definite trend in the occurrence of accidents in the vicinity of urban areas. This result was expected, since a higher amount of conflicts characterises these zones due to the presence of pedestrians, motorcyclists, intersections and, mostly, drastic changes in land use. Figure 9 shows the result of the same analysis for the potential accident risks detected on the road. Similar spatial distribution patterns are observed at the scene of deaths and injuries, noting that near urban areas there is a greater presence of a risk of crashes. Both, arterial and collector roads, follow the same tendency regarding accident risks.

Figures 10 and 11 present the maps produced by normalisation with the areas that have statistical significance. In the case of injury or fatality, the most critical areas are in the vicinity of the urbanised areas of Route 25 and sectors near Barranquilla (the Capital of Atlantic Department) for Route 90 and Route $90 \mathrm{~A}$. Based on the risk criteria, the critical areas identified are mainly in roads linking municipal headwaters, which have a higher density near Barranquilla, located in the north-east corner of the Atlantic Department.

The highest frequency of crashes and risks sectors is shown in Figure 12. The map is generated from the intersection areas between FWI and those with a potential risk of accidents with high statistical significance. It can be noted that critical sectors are in proximity to urban areas. It is in these road sections that the implementation of control measures is recommended with greater urgency since they are likely to have the most significant impact on increasing road safety. In Figure 12 it is also noted that some of these critical areas already have speed controls.

From the previous step and the site of the current

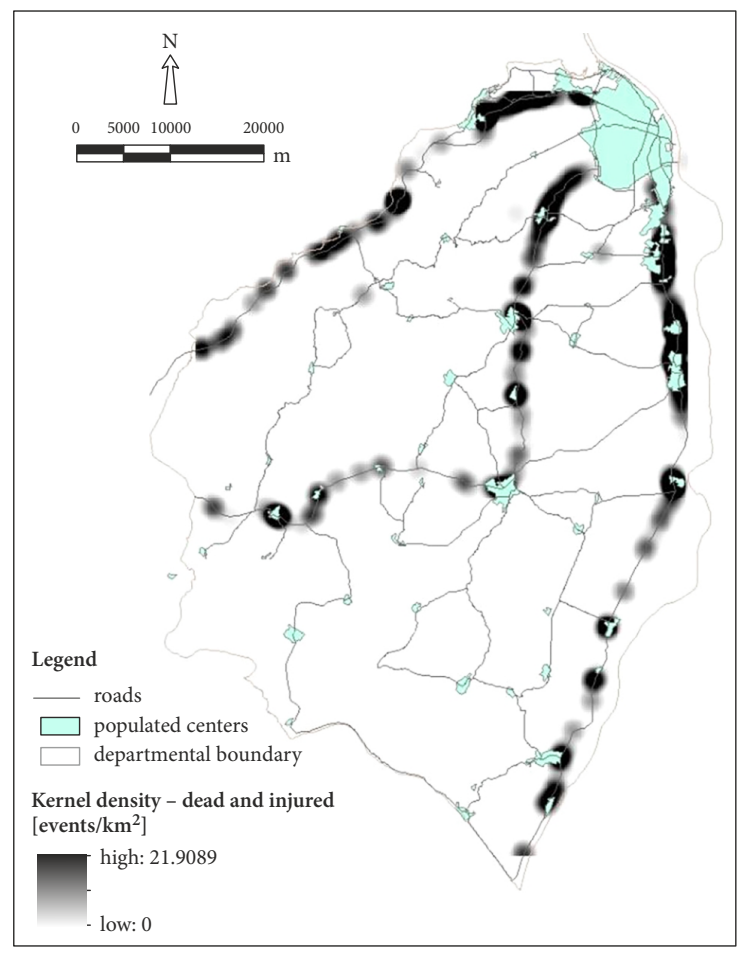

Figure 8. Spatial distribution kernel of FWI cameras, the proposed location for the new cameras is defined in Figure 13 since in those places there will be expected a more significant impact in the control of the speed. This methodology identifies 17 points for the location of photo-radars, excluding critical areas where cameras are already present. After an additional study of the characteristics of each specific zone, presented in Table 3, the analysis recommended that thirteen should be fixed cameras while four should be mobile ones. In the case of having budget constraints for attending all critical sectors, priority should be given to the arterial routes, since they are the ones with the highest flow of vehicles in the entrance/exit areas or within urban areas where the largest number of accidents occurs. Also, areas with road hazards due to geometric deficiencies must be considered as priorities. Analysing the mobile cameras in the proposal, they are all in sectors of high-risk and high-speed variance. It is worth mentioning the case of mobile cameras on Route 25 which, in addition to being a section with high accident rates and presence of risks on the road, has a very long straight stretch of more than $15 \mathrm{~km}$ where vehicles tend to exceed the limit allowed according to the records of the performed assessment.

We compared our results with a ZIP model to validate the location of the speed cameras. We selected the ZIP model because the occurrence of traffic crashes by road sections are events with a low probability; so it is usual to find a greater number of zeros at count than expected in a Poisson or negative binomial distribution. According to UCLA (2021), excess zeros can be modelled independently. The ZIP model has two parts: a Poisson count model, and a binomial or a binary logit model that is used to predict excess zeros at roads. The ZIP model consid-

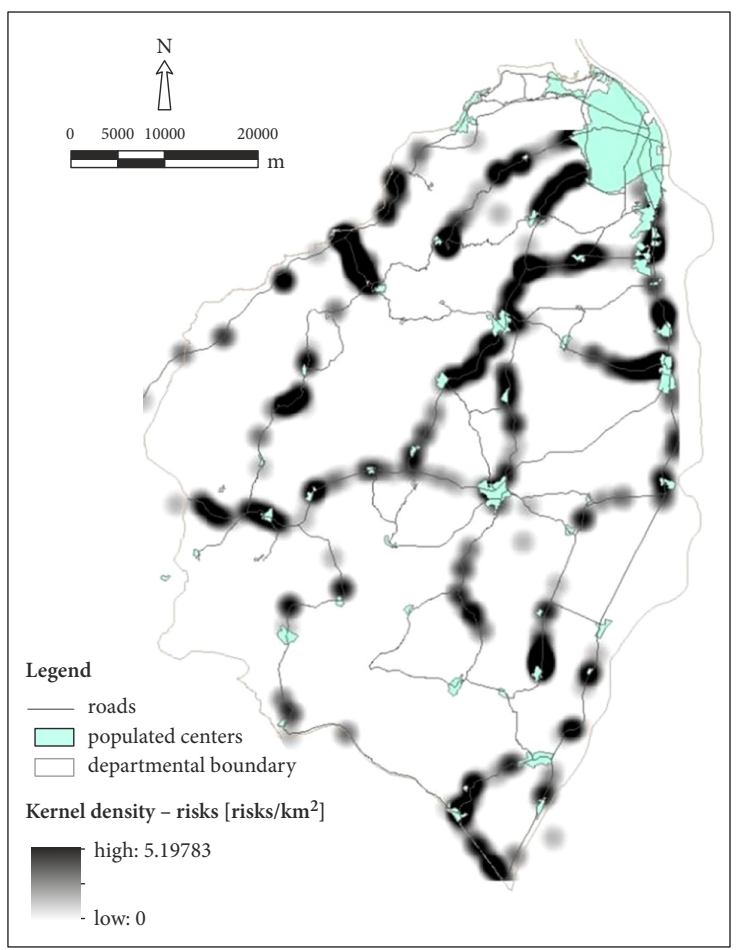

Figure 9. Density of risks by kernel method 


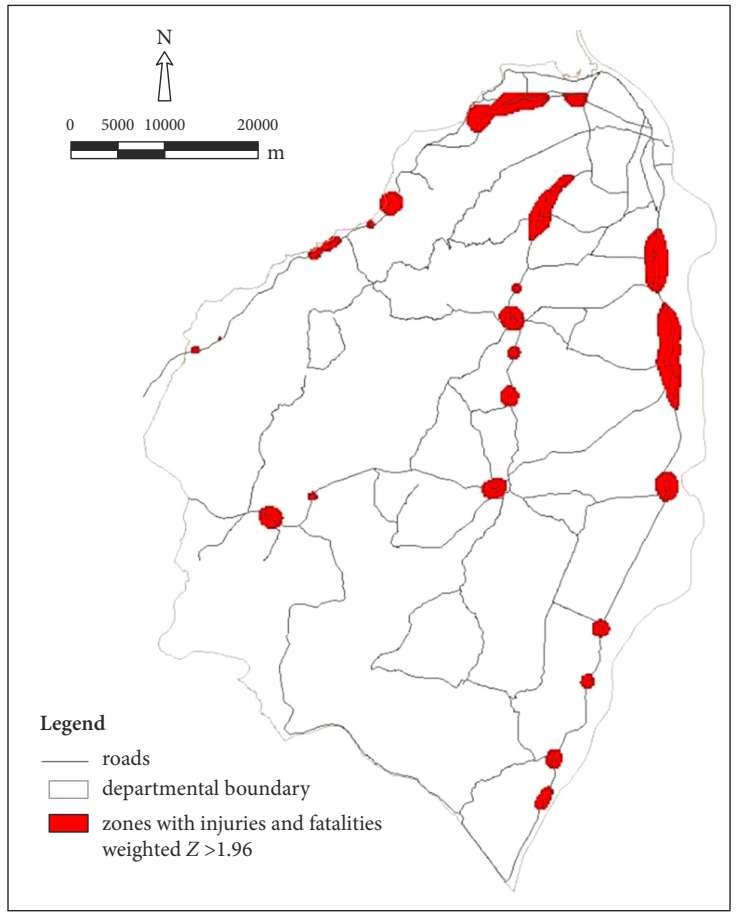

Figure 10. Zones with statistical significance of FWI

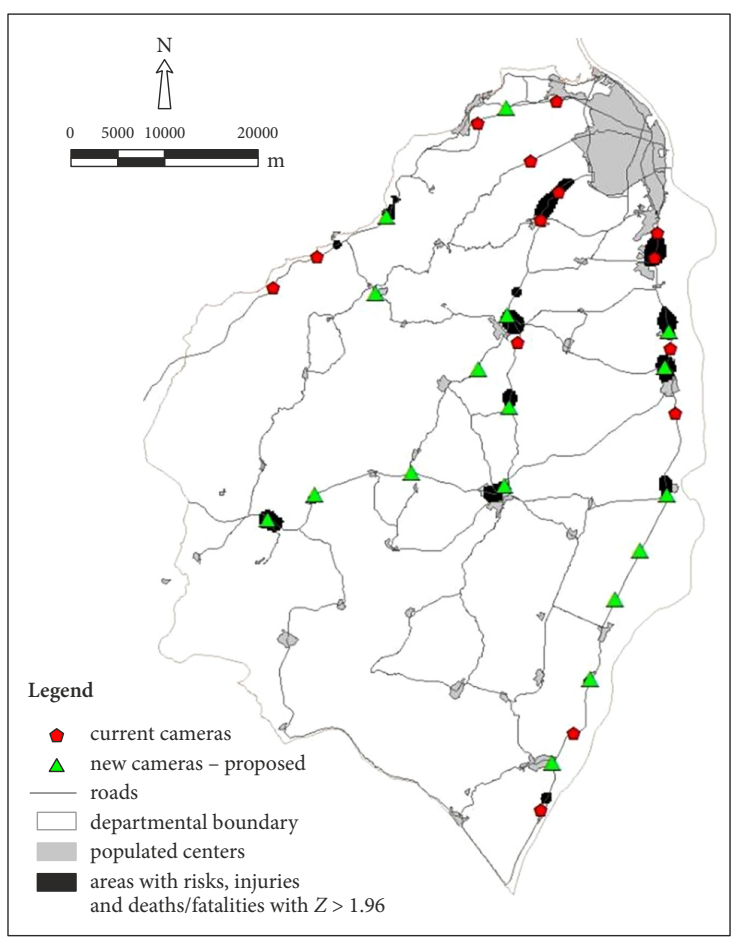

Figure 12. Risks, injuries and FWI areas with $Z \geq 1.96$

ers that the independent variable $y$ that is the number of events in the period is estimated as follows Washington et al. (2020):

$$
y_{i}=0
$$

and its probability: $p_{i}+\left(1-p_{i}\right) \cdot e^{-\mu_{i}}$;

$\quad y_{i}=y$
and its probability: $\frac{\left(1-p_{i}\right) \cdot e^{-\mu_{i}} \cdot \mu_{i}^{y}}{y !}$;

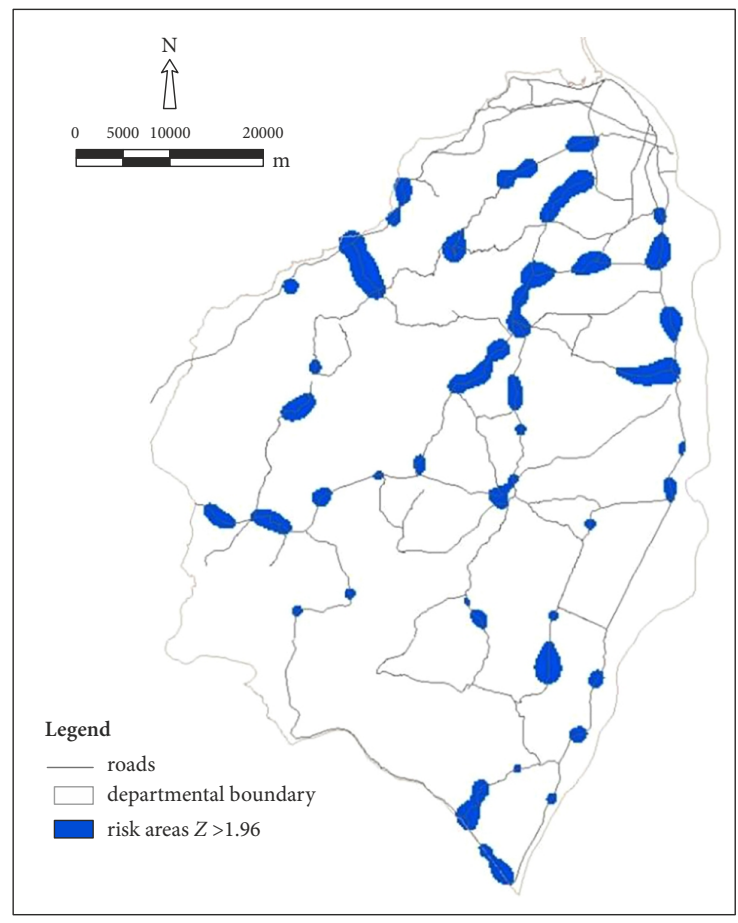

Figure 11. Risk areas with statistical significance

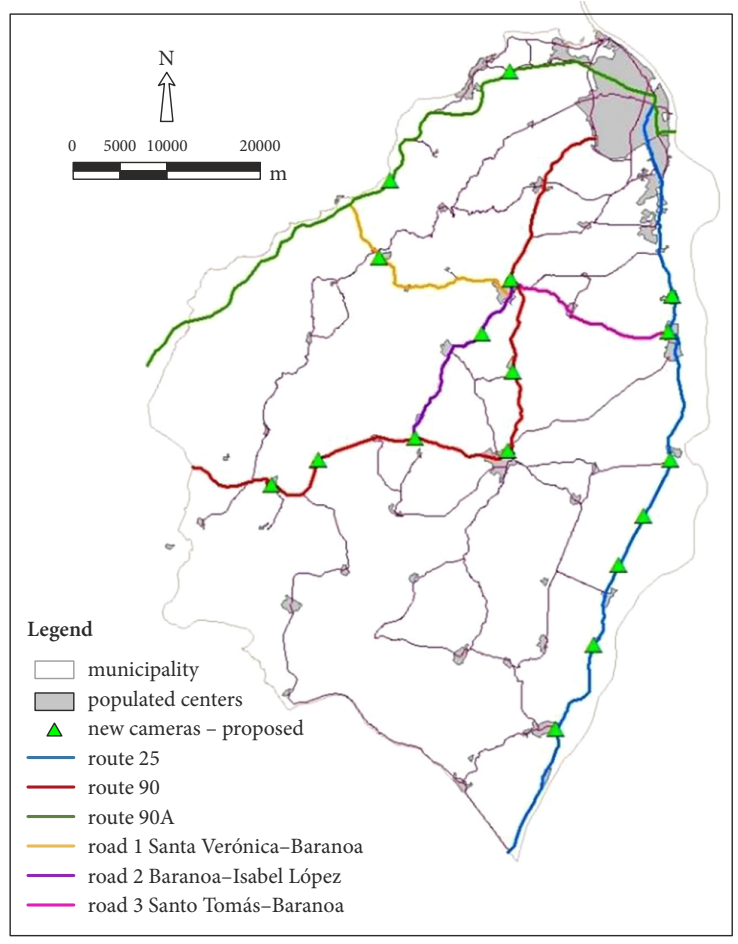

Figure 13. Proposal for camera location

$$
\mu_{i}=e^{\beta \cdot X_{i}}
$$

where: $y$ is independent variable; $p_{i}$ is the probability of being in the zero state; $\mu_{i}$ is the expected numbers of events per period (the most used relationship between $\mu_{i}$ and the vector of explanatory variables is the log-linear model); $\beta$ is a vector of parameters to be estimated; $X_{i}$ is a set of explanatory variables. 
This analysis was performed only over the arterial road system because it is the only one that has FWI data available. The roads were divided into sections less than $1 \mathrm{~km}$, and the count of the number of accidents was made for each section. Zero accidents were recorded in about 53\% of the sections. Two explanatory variables were significant: speed $[\mathrm{km} / \mathrm{h}]$ and the product length of the section $\times \mathrm{ADT}$ [vehicle- $\mathrm{km} /$ day]. Table 4 shows the estimates of the ZIP model ( $t$-statistics in parenthesis).

Figure 14 presents the overlapping between the FWI zones with high statistical significance from our methodology and the hot-spots obtained from the ZIP model.
Table 4. ZIP regression of the number of crashes

\begin{tabular}{|l|c|c|}
\cline { 2 - 3 } \multicolumn{1}{l|}{} & Zero crashes & Poisson crashes \\
\hline $\begin{array}{l}\text { Dispersion for negative } \\
\text { binomial }\end{array}$ & $0.2261(10.76)$ & - \\
\hline Constant & $1.0160(1.99)$ & $0.2525(1.96)$ \\
\hline Speed parameter & $0.0075(0.83)$ & $0.0171(8.29)$ \\
\hline Length $\times$ ADT & - & $0.0485(13.89)$ \\
\hline Akaike information criterion & 1383.7 & 3511.3 \\
\hline Number of observations & - & 315 \\
\hline
\end{tabular}

Note: $t$-statistics in parenthesis.

Table 3. Registration of proposed cameras

\begin{tabular}{|c|c|c|c|c|}
\hline \multirow{2}{*}{$\begin{array}{l}\text { Road } \\
\text { type }\end{array}$} & \multirow{2}{*}{ Road } & \multirow{2}{*}{ Characteristics of the sector } & \multicolumn{2}{|c|}{ Camera } \\
\hline & & & fixed & mobile \\
\hline \multirow{9}{*}{$\begin{array}{l}\text { Principal } \\
\text { arterial } \\
\text { system }\end{array}$} & \multirow{4}{*}{ Route 25} & high accident rate, risks on the road and the presence of a populated centre & 2 & - \\
\hline & & risks in the road and differences in speed between the paths that converge & 1 & - \\
\hline & & high-speeds for long, straight stretches and risks on the road & - & 2 \\
\hline & & high accident rate and entrance to a populated centre & 1 & - \\
\hline & \multirow{3}{*}{ Route 90} & high accident rate and entrance area to a populated centre & 2 & - \\
\hline & & high accident rate, risks on the road and entrance area to a populated centre & 3 & - \\
\hline & & risks in the road and differences in speed between the paths that converge & - & 1 \\
\hline & \multirow{2}{*}{ Route 90A } & high accident rate and risks present on the road. & 1 & - \\
\hline & & risks in the road and differences in speed between the paths that converge & 1 & - \\
\hline \multirow[t]{3}{*}{$\begin{array}{l}\text { Collector } \\
\text { system }\end{array}$} & $\begin{array}{l}\text { Road 1: } \\
\text { Santa Verónica-Baranoa }\end{array}$ & high-speed, presence of risks on the road and presence of school zone & 1 & - \\
\hline & \begin{tabular}{|l|} 
Road 2: \\
Baranoa-Isabel López \\
\end{tabular} & high-speed and presence of risks on the road & - & 1 \\
\hline & $\begin{array}{l}\text { Road 3: } \\
\text { Sto Tomás-Baranoa }\end{array}$ & presence of risks in the way and entrance to a populated centre & 1 & - \\
\hline
\end{tabular}

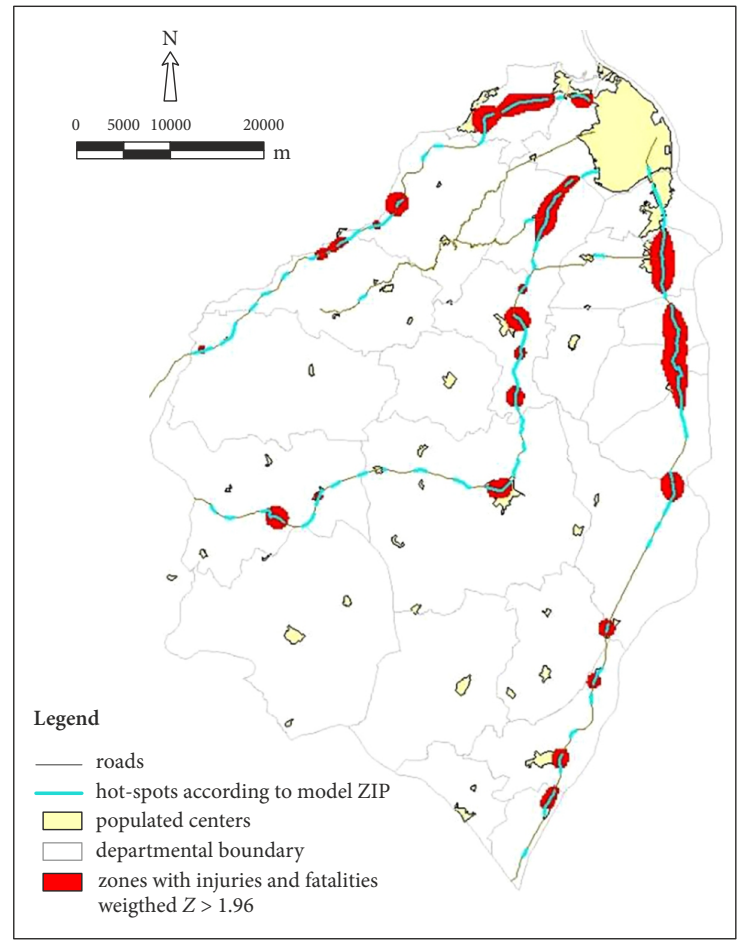

Figure 14. Hot-spots overlapping considering ZIP model and FWI data

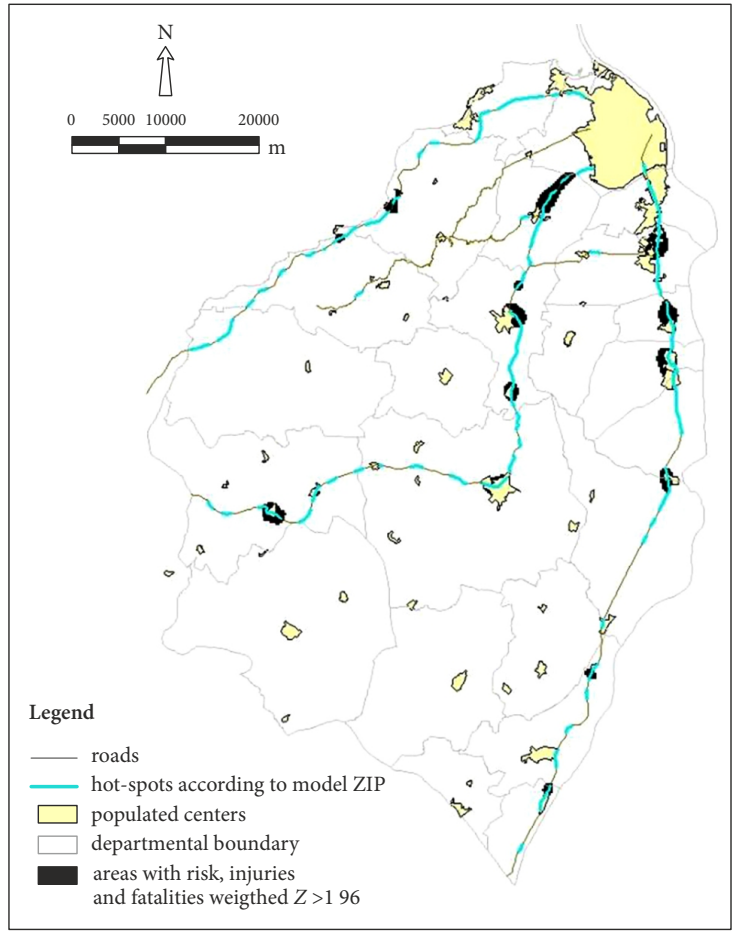

Figure 15. Hot-spots overlapping considering ZIP model and FWI with accident risk data 
Although the number of hot-spots in the ZIP model is higher than the ones proposed in our methodology, areas with a critical rate of accident present high coincidence. A similar pattern can be seen in Figure 15, which shows the coincidence of the critical zones obtained from the ZIP model and those from our methodology, but considering FWI and potential risky zones.

Additionally, Figure 16 illustrates the results of spatial autocorrelation analysis using the Moran index. The null hypothesis is that variables follow a random distribution. Given that the Moran index is greater than zero and the $Z$ score is 30.59 , the probability that this observed clustered pattern could be random is less than $1 \%$.

Some limitations of this methodology should be acknowledged. It is worth mentioning the possible presence of endogeneity, given that by not taking into account some variables, the results can be affected, generating an error greater than the one reported. Also, the method requires information about the status of road infrastructure that in many cases is not available for the entire study area. In other cases, it is possible to obtain this information but with relevant differences in the level of detail or reliability. The method assumes that the precision in the location of events is high, which does not always happen.

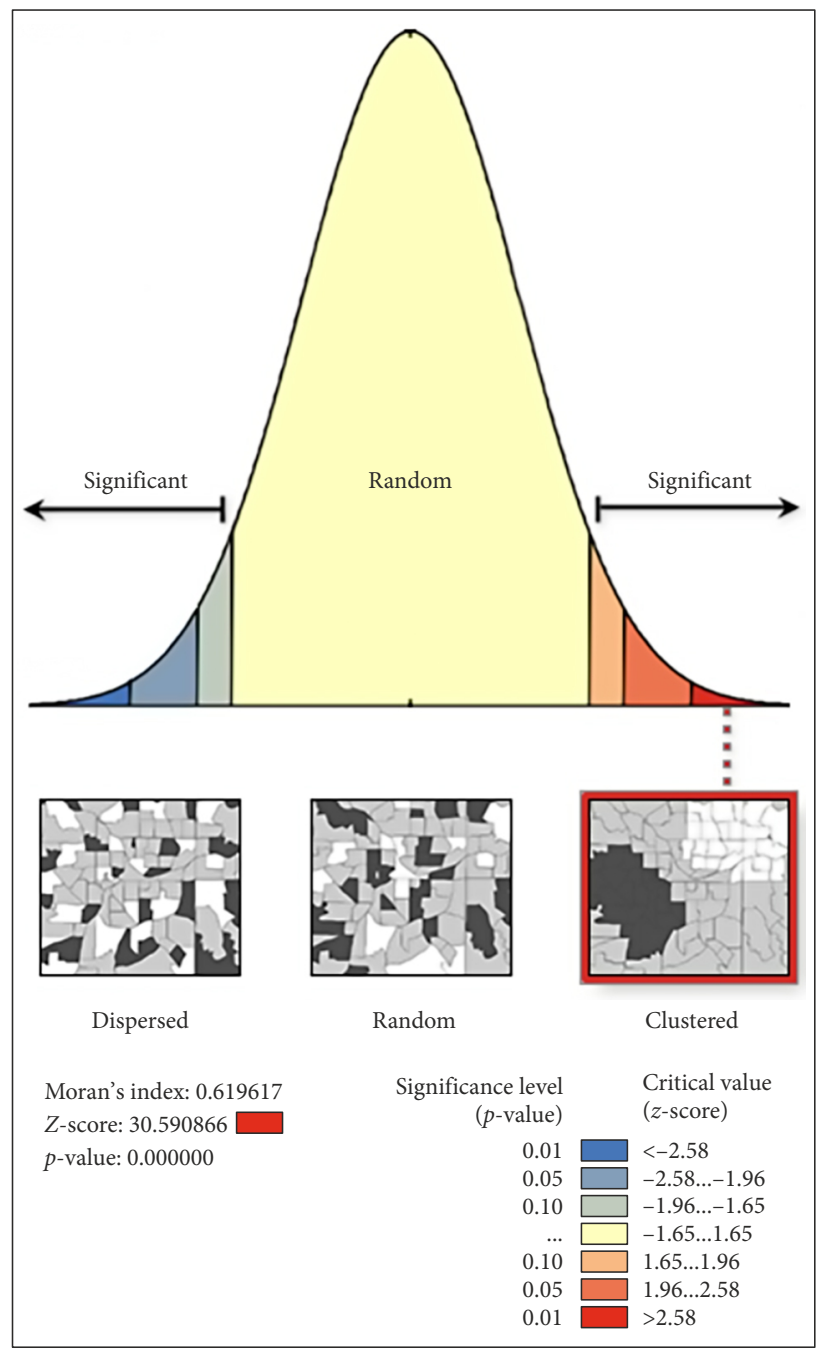

Figure 16. Spatial autocorrelation report

\section{Conclusions}

This paper proposes a methodology that allows for the identification of critical areas in road safety where establishing speed controls with photo-radars in rural routes. The method uses information from records of injuries, fatalities, and accident risks obtained from road safety audits. The approach considers relevant variables and can be replicable to other areas of study for the reduction of accidents.

The case study in Colombia lets us conclude that the sectors with the highest risk and best inclined to establish photo-radar controls on rural roads are in proximity to urban areas. Also, sectors with a high frequency of accidents and with the presence of risks on the road or characterised by high-speed variance in short sections were identified as critical. It is recommended to establish, in some cases, fixed radars and, in others, mobile cameras. The latter is useful to avoid strategic behaviours of drivers who already know the location of fixed cameras and who exceed the limits in other sectors where there are no cameras installed.

The proposed methodology can be applied in a continuous way using the registries that the entities that maintain databases of the accidents periodically provide and thus to be able to carry out the tracking of statistics to evaluate the effectiveness of the measures. In any case, speed control measures and infrastructure interventions must be accompanied by education and monitoring campaigns for other offences, with particular emphasis on the most vulnerable users (pedestrians, cyclists, and motorcyclists). It should be noted that not all problems are solved only with speed controls, there are other risks on the road that can be handled by the application of low-cost countermeasures.

Speed controls should not be a stand-alone policy; they should be framed within a management system of road safety that allows for establishing a planning horizon in the medium and long-term to measure the effectiveness of the controls at the critical points from posterior evaluations. These permit determining compliance with speed reduction and accident objectives; identifying benefits and costs generated by established controls and improving practice in the establishment and variables considered for regulations in road safety that can be implemented in the future with a greater probability of success.

The method is particularly useful in areas where historical traffic crashes information is lacking. For instance, in developing countries, it is possible to find detailed records regarding crashes for the arterial road system; however, for the collector and local road systems, such information is not always available. The proposed approach combines information from different sources, including a road safety audit, which can be done as part of the analysis.

Finally, this research, besides being applicable in any context, can be enriched by the inclusion of additional variables. The method can also be adapted to urban areas, where there are higher conflicts and crashes density. 


\section{Author contributions}

Garis Coronell, Julián Arellana and Víctor Cantillo conceived the study and design.

Garis Coronell, Julián Arellana and Víctor Cantillo were responsible for acquisition, analysis and interpretation of data.

Authors participate in drafting the article, revision and final approval of the version to be submitted.

\section{Disclosure statement}

Authors have not financial, professional, or personal interest.

\section{References}

Aarts, L.; Van Schagen, I. 2006. Driving speed and the risk of road crashes: a review, Accident Analysis \& Prevention 38(2): 215-224. https://doi.org/10.1016/j.aap.2005.07.004

Akgüngör, A. P.; Doğan, E. 2009. An artificial intelligent approach to traffic accident estimation: Model development and application, Transport 24(2): 135-142.

https://doi.org/10.3846/1648-4142.2009.24.135-142

Aljassar, A. H.; Ali, M. A.; Al-Anzi, M. S. 2004. An investigation on the effect of traffic cameras on road safety in Kuwait, in 2nd Gulf Conference on Roads, 14-18 March 2004, Abu Dhabi, UAE, 1-11.

Anderson, T. 2007. Comparison of spatial methods for measuring road accident 'hotspots': a case study of London, Journal of Maps 3(1): 55-63. https://doi.org/10.1080/jom.2007.9710827

ARISTO Consultores Ltda. 2011. Definición de metodología para la localización de equipos de fiscalización automática relacionados con seguridad vial: informe final. Ministerio de Transportes y Telecomunicaciones (MTT). Gobierno de Chile. 84 p. (in Spanish). Available from Internet: http://www.sectra.gob. $\mathrm{cl} /$ biblioteca/detalle1.asp? $\mathrm{mfn}=2927$

Ayati, E.; Abbasi, E. 2011. Investigation on the role of traffic volume in accidents on urban highways, Journal of Safety Research 42(3): 209-214.

https://doi.org/10.1016/j.jsr.2011.03.006

Berkuti, C.; Osburn, W. 1998. Photo enforcement in the Wild West: national city's experience with photo radar enforcement program, in 1998 Compendium Of Technical Papers, Institute Of Transportation Engineers, Washington, DC, US, 112-117.

Blais, E.; Carnis, L. 2015. Improving the safety effect of speed camera programs through innovations: evidence from the French experience, Journal of Safety Research 55: 135-145. https://doi.org/10.1016/j.jsr.2015.08.007

Buzai, G. D.; Baxendale, C. A. 2015. Análisis socioespacial con sistemas de información geográfica marco conceptual basado en la teoría de la geografía, Ciencias Espaciales 8(2): 391-408. (in Spanish). https://doi.org/10.5377/ce.v8i2.2089

Cameron, M.; Newstead, S.; Diamantopoulou, K.; Oxley, P. 2003. The Interaction between Speed Camera Enforcement and SpeedRelated Mass Media Publicity in Victoria. Report No 201. Accident Research Centre, Monash University, Clayton, Victoria, Australia 130 p. Available from Internet: https://www. monash.edu/_data/assets/pdf_file/0020/216821/The-interaction-between-speed-camera-enforcement-and-speed-relatedmass-media-publicity-in-Victoria.pdf

Cardozo, O. D.; Bondar, C. E.; Odriozola, J. G. 2010. Localización óptima de expendios de carne porcina con sistemas de in- formación geográfica en la ciudad de Resistencia, Argentina, Cuadernos de Geografía: Revista Colombiana de Geografía (19): 87-96. (in Spanish).

https://doi.org/10.15446/rcdg.n19.16850

Carnis, L. 2008. Automated speed detection and sanctions system: application and evaluation in France, Journal of Intelligent Transportation Systems: Technology, Planning, and Operations 12(2): 75-85. https://doi.org/10.1080/15472450802023345

Chang, L.-Y.; Chen, W.-C. 2005. Data mining of tree-based models to analyze freeway accident frequency, Journal of Safety Research 36(4): 365-375.

https://doi.org/10.1016/j.jsr.2005.06.013

Chen, C.; Zhang, G.; Liu, X. C.; Ci, Y.; Huang, H.; Ma, J.; Chen, Y.; Guan, H. 2016. Driver injury severity outcome analysis in rural interstate highway crashes: a two-level Bayesian logistic regression interpretation, Accident Analysis \& Prevention 97: 69-78. https://doi.org/10.1016/j.aap.2016.07.031

Christie, S. M.; Lyons, R. A.; Dunstan, F. D.; Jones, S. J. 2003. Are mobile speed cameras effective? A controlled before and after study, Injury Prevention 9(4): 302-306.

https://doi.org/10.1136/ip.9.4.302

CoNaSeT. 2002. Informe Técnico de Equipos de Registro de Infracciones. Comisión Nacional de Seguridad de Tránsito (CoNa$\mathrm{SeT}$ ), Chile. (in Spanish). Available from Internet: https://www.conaset.cl

CorMagdalena. 2003. Actualización de la Cartografía Básica a Escala 1:100.000 de la Zona Norte de la Cuenca del Río Magdalena. Corporación Autónoma Regional del Río Grande de la Magdalena (CorMagdalena), Bogotá, Colombia. (in Spanish). Available from Internet: http://www.cormagdalena.gov.co

CFPV. 2013. Evaluación de la Seguridad Vial en Rutas Asignadas a la Red Vial Nacional de Acuerdo a Las Capacitaciones Sobre la Metodología de Evaluación de Seguridad Vial iRAP. Corporación Fondo de Prevención Vial (CFPV), Bogotá, Colombia. (in Spanish).

Dai, D. 2012. Identifying clusters and risk factors of injuries in pedestrian-vehicle crashes in a GIS environment, Journal of Transport Geography 24: 206-214.

https://doi.org/10.1016/j.jtrangeo.2012.02.005

DANE. 2006. Censo General 2005. Departamento Administrativo Nacional de Estadística (DANE), Colombia. (in Spanish). Available from Internet: http://www.dane.gov.co/index. php/estadisticas-por-tema/demografia-y-poblacion/censogeneral-2005-1

DDOT. 2013. Speed Limit and Safety Nexus Studies for Automated Enforcement Locations in the District of Columbia: 700 Block Maryland Avenue NE. District Department of Transportation (DDOT), Washington, DC, US. 9 p. Available from Internet: http://ddotfiles.com/SpeedCameras/Ward6_Proposed/700_ MarylandAve_NE.pdf

De Pauw, E.; Daniels, S.; Brijs, T.; Hermans, E.; Wets, G. 2014a. An evaluation of the traffic safety effect of fixed speed cameras, Safety Science 62: 168-174. https://doi.org/10.1016/j.ssci.2013.07.028

De Pauw, E.; Daniels, S.; Brijs, T.; Hermans, E.; Wets, G. 2014 b. Behavioural effects of fixed speed cameras on motorways: Overall improved speed compliance or kangaroo jumps?, Accident Analysis \& Prevention 73: 132-140. https://doi.org/10.1016/j.aap.2014.08.019

Delaney, A.; Ward, H.; Cameron, M.; Williams, A. F. 2005. Controversies and speed cameras: lessons learnt internationally, Journal of Public Health Policy 26(4): 404-415. https://doi.org/10.1057/palgrave.jphp.3200044

DfT. 2007. Use of Speed and RedLight Cameras for Traffic Enforcement: Guidance on Deployment, Visibility and Signing. DfT 
Circular 01/2007. Department for Transport (DfT), London, UK. 12 p. Available from Internet: https://assets.publishing. service.gov.uk/government/uploads/system/uploads/attachment_data/file/465165/dft-circular-0107.pdf

DNIT. 2012. Fiscalização Eletrônica Reduz Acidentes e Vítimas nas Rodovias. Departamento Nacional de Infraestrutura de Transportes (DNIT), Ministério da Infraestrutura, Brasil. (in Portuguese). Available from Internet: https://estradas.com. br/fiscalizacao-eletronica-reduz-acidentes-e-vitimas-nasrodovias

Elvik, R. 2009. The Power Model of the Relationship between Speed and Road Safety: Update and New Analyses. TØI Report 1034/2009. Institute of Transport Economics (TØI), Oslo, Norway, 82 p. Available from Internet: https://www.toi.no/getfile.php?mmfileid=13206

Erdogan, S.; Yilmaz, I.; Baybura, T.; Gullu, M. 2008. Geographical information systems aided traffic accident analysis system case study: city of Afyonkarahisar, Accident Analysis \& Prevention 40(1): 174-181. https://doi.org/10.1016/j.aap.2007.05.004

ETSC. 1995. Reducing Traffic Injuries Resulting from Excess and Inappropriate Speed. European Transport Safety Council (ETSC), Brussels, Belgium. 40 p. Available from Internet: http://archive.etsc.eu/documents/Reducing\%20traffic\%20injuries\%20 from $\% 20$ excess $\% 20$ and $\% 20$ inappropriate $\% 20$ speed.pdf

Goldenbeld, C.; Van Schagen, I. 2005. The effects of speed enforcement with mobile radar on speed and accidents: An evaluation study on rural roads in the Dutch province Friesland, Accident Analysis \& Prevention 37(6): 1135-1144. https://doi.org/10.1016/j.aap.2005.06.011

Gómez-Barroso, D.; López-Cuadrado, T.; Llácer, A.; PalmeraSuárez, R.; Fernández-Cuenca, R. 2015. Análisis espacial de los accidentes de tráfico con víctimas mortales en carretera en España, 2008-2011, Gaceta Sanitaria 29(Suppl. 1): 24-29. (in Spanish). https://doi.org/10.1016/j.gaceta.2015.02.009

GRSP. 2008. Speed Management: a Road Safety Manual for Decision-Makers and Practitioners. Global Road Safety Partnership (GRSP), Geneva, Switzerland. 191 p. Available from Internet: http://apps.who.int/iris/bitstream/handle/10665/43915/9782940395040_eng.pdf

Hadayeghi, A.; Shalaby, A. S.; Persaud, B. N. 2010. Development of planning level transportation safety tools using geographically weighted Poisson regression, Accident Analysis \& Prevention 42(2): 676-688. https://doi.org/10.1016/j.aap.2009.10.016

Harwood, D. W.; Bauer, K. M.; Gilmore, D. K.; Souleyrette, R.; Hans, Z. N. 2010. Validation of U.S. road assessment program star rating protocol: application to safety management of U.S. roads, Transportation Research Record: Journal of the Transportation Research Board 2147: 33-41.

https://doi.org/10.3141/2147-05

He, J.; King, M.; Watson, B.; Rakotonirainy, A.; Fleiter, J. 2013. Speed enforcement in China: National, provincial and city initiatives and their success, Accident Analysis \& Prevention 50: 282-288. https://doi.org/10.1016/j.aap.2012.04.017

Hess, S.; Polak, J. 2003. Effects of speed limit enforcement cameras on accident rates, Transportation Research Record: Journal of the Transportation Research Board 1830: 25-33. https://doi.org/10.3141/1830-04

Høye, A. 2015. Safety effects of fixed speed cameras - an empirical Bayes evaluation, Accident Analysis \& Prevention 82: 263-269. https://doi.org/10.1016/j.aap.2015.06.001

IGAC. 2011. SIGOT: Sistema de Información Geográfica Para la Planeación y el Ordenamiento Territorial. Instituto Geográfico Agustín Codazzi (IGAC), Bogotá, Colombia. (in Spanish). Available from Internet: https://sigot.igac.gov.co
INMLCF. 2015. Forensis 2014: Datos Para la Vida. Instituto Nacional de Medicina Legal y Ciencias Forenses (INMLCF), Bogota, Colombia. (in Spanish). Available from Internet: https://www.medicinalegal.gov.co

INVÍAS. 2015. Volúmenes de Tránsito: Documentos Técnicos. Instituto Nacional de Vías (INVÍAS), Bogotá, Colombia. (in Spanish). Available from Internet: https://invias.gov.co

Koike, H.; Morimoto, A.; Hanzawa, Y.; Shiraishi, N. 2000. Development of hazard map using GIS to reduce traffic accidents, in Eighth International Conference on Computing in Civil and Building Engineering (ICCCBE-VIII), 14-16 August 2000, Stanford, CA, US, 217-224.

https://doi.org/10.1061/40513(279)28

Li, H.; Graham, D. J. 2016. Heterogeneous treatment effects of speed cameras on road safety, Accident Analysis \& Prevention 97: 153-161. https://doi.org/10.1016/j.aap.2016.09.007

Luna González, L.; Chias Becerril, L. 1999. El uso de SIG en el análisis de la distribución de accidentes en carreteras: el caso de Tamaulipas, México, Investigaciones Geográficas 40: 148-162. (in Spanish). https://doi.org/10.14350/rig.59100

Ma, Z.; Zhao, W.; Chien, S. I.-J.; Dong, C. 2015. Exploring factors contributing to crash injury severity on rural two-lane highways, Journal of Safety Research 55: 171-176. https://doi.org/10.1016/j.jsr.2015.09.003

Mäkinen, T.; Zaidel, D. M.; Andersson, G.; Biecheler-Fretel, M.-B.; Christ, R.; Cauzard, J.-P.; Elvik, R.; Goldenbeld, C.; Gelau, C.; Heidstra, J.; Jayet, M.-C.; Nilsson, G.; Papaioanou, P.; Quimby, A.; Rehnova, V.; Vaa, T. 2003. Traffic Enforcement in Europe: Effects, Measures, Needs and Future. Final Report of the ESCAPE Consortium. The "Escape" Project, Contract No RO-98-RS.3047. 138 p. Available from Internet: https:// ec.europa.eu/transport/road_safety/sites/default/files/pdf/ projects_sources/escape_final_report.pdf

Martínez, A.; Arellana, J.; Coronell, G.; Cantillo, V. 2014. Análisis geoespacial de muertos y heridos por accidentes de tráfico en zonas urbanas: aplicación a Barranquilla, Colombia, in XVIII Congreso Panamericano de Ingeniería de Tránsito, Transporte y Logística, PANAM 2014, 11-13 de junio de 2014, Santander, Cantabria, España (in Spanish).

Novoa, A. M.; Pérez, K.; Santamariña-Rubio, E.; MaríDell'Olmo, M.; Tobías, A. 2010. Effectiveness of speed enforcement through fixed speed cameras: a time series study, Injury Prevention 16(1): 12-16.

https://doi.org/10.1136/ip.2008.021485

OECD. 2006. Speed Management. Transport Research Centre, Organisation for Economic Co-operation and Development (OECD). 285 p. Available from Internet: https://www.itfoecd.org/sites/default/files/docs/06speed.pdf

Oei, H.-L. 1996. Automatic speed management in the Netherlands, Transportation Research Record: Journal of the Transportation Research Board 1560: 57-64. https://doi.org/10.3141/1560-09

Paredes, R. D.; Rizzi, L. I.; Valenzuela, J. 2006. ¿Cazabobos o salvavidas?: la economía política de los fotorradares en Chile, Estudios de Economía 33(2): 97-115. (in Spanish).

Pikūnas, A.; Pumputis, V.; Sadauskas, V. 2004. The influence of vehicles speed on accident rates and their consequences, Transport 19(1): 15-19. https://doi.org/10.3846/16484142.2004.9637946

Povey, L. J.; Frith, W. J.; Keall, M. D. 2003. An Investigation of the Relationship between Speed Enforcement, Vehicle Speeds and Injury Crashes in New Zealand. Transportation Group, New Zealand. 12 p. Available from Internet: http://www.transportationgroup.nz/papers/2003/01_Povey_Keall_Frith.pdf 
Prasannakumar, V.; Vijith, H.; Charutha, R.; Geetha, N. 2011. Spatio-temporal clustering of road accidents: GIS based analysis and assessment, Procedia - Social and Behavioral Sciences 21: 317-325. https://doi.org/10.1016/j.sbspro.2011.07.020

Rodríguez Ojeda, L. 2014. Construcción de kernels y funciones de densidad, in Repositorio Dspace. 18 p. (in Spanish). Available from Internet:

http://www.dspace.espol.edu.ec/handle/123456789/25019

Rosenblatt, M. 1956. Remarks on some nonparametric estimates of a density function, The Annals of Mathematical Statistics 27(3): 832-837. https://doi.org/10.1214/aoms/1177728190

Shim, J.; Park, S. H.; Chung, S.; Jang, K. 2015. Enforcement avoidance behavior near automated speed enforcement areas in Korean expressways, Accident Analysis \& Prevention 80: 57-66. https://doi.org/10.1016/j.aap.2015.03.037

Silverman, B. W. 1998. Density Estimation for Statistics and Data Analysis. Routledge. $176 \mathrm{p}$. https://doi.org/10.1201/9781315140919

Steenberghen, T.; Aerts, K.; Thomas, I. 2010. Spatial clustering of events on a network, Journal of Transport Geography 18(3): 411-418. https://doi.org/10.1016/j.jtrangeo.2009.08.005

Steenberghen, T.; Dufays, T.; Thomas, I.; Flahaut, B. 2004. Intraurban location and clustering of road accidents using GIS: a Belgian example, International Journal of Geographical Information Science 18(2): 169-181.

https://doi.org/10.1080/13658810310001629619

Theofilatos, A. 2017. Incorporating real-time traffic and weather data to explore road accident likelihood and severity in urban arterials, Journal of Safety Research 61: 9-21. https://doi.org/10.1016/j.jsr.2017.02.003

Tulu, G. S.; Washington, S.; Haque, M.; King, M. J. 2015. Investigation of pedestrian crashes on two-way two-lane rural roads in Ethiopia, Accident Analysis \& Prevention 78: 118-126. https://doi.org/10.1016/j.aap.2015.02.011

Turner, S.; Polk, A. E. 1998. Overview of automated enforcement in transportation, ITE Journal 68(6): 20-29.

UCLA. 2021. Zero-Inflated Poisson Regression - R Data Analysis Examples. UCLA Statistical Consulting, Institute for Digital Research and Education, Los Angeles, CA, US. Available from Internet: https://stats.idre.ucla.edu/r/dae/zip

UniNorte. 2013. Estudio de Los Puntos Críticos de Accidentalidad en Las Vías del Departamento del Atlántico. Universidad del Norte (UniNorte), Barranquilla, Colombia. (in Spanish).

Vecino-Ortiz, A. I.; Hyder, A. A. 2014. The use of cost-benefit analysis in road assessments: a methodological inquiry, Injury Prevention 20(1): 50-53. https://doi.org/10.1136/injuryprev-2012-040708

Washington, S.; Karlaftis, M.; Mannering, F.; Anastasopoulos, P. 2020. Statistical and Econometric Methods for Transportation Data Analysis. Chapman and Hall/CRC. 496 p. https://doi.org/10.1201/9780429244018

Weber, R.; Jahrig, T. 2010. “AOSI” improving road safety on rural roads in Germany, in 4th International Symposium on Highway Geometric Design, 2-5 June 2010, Valencia, Spain, 1-8.

WHO. 2015. Global Status Report on Road Safety 2015. World Health Organization (WHO). 340 p. Available from Internet: https://www.afro.who.int/sites/default/files/2017-06/ 9789241565066_eng.pdf
WHO. 2009. Global Status Report on Road Safety: Time for Action. World Health Organization (WHO). 301 p. Available from Internet: https://apps.who.int/iris/bitstream/handle/ 10665/44122/9789241563840_eng.pdf

Young, J.; Park, P. Y. 2014. Hotzone identification with GIS-based post-network screening analysis, Journal of Transport Geography 34: 106-120.

https://doi.org/10.1016/j.jtrangeo.2013.11.007 